Tarih Kültür ve Sanat Araştırmaları Dergisi

Revue des Recherches en Histoire Culture et Art

مجلة البحوث التاريخية والثقافية والفنية
Vol. 6, No. 4, September 2017

Copyright (C) Karabuk University

http://kutaksam.karabuk.edu.tr

\title{
DOI: 10.7596/taksad.v6i4.1163
}

Citation: Mukhametzyanov, R., Nugaev, F., \& Muhametzyanova, L. (2017). History of Accounting Development. Journal of History Culture and Art Research, 6(4), 1227-1236. doi:http://dx.doi.org/10.7596/taksad.v6i4.1163

\section{History of Accounting Development}

\author{
Rinaz Z. Mukhametzyanov ${ }^{1}$, Fatih Sh. Nugaev $^{2}$ \\ Lyaisan Z. Muhametzyanova ${ }^{3}$
}

\begin{abstract}
Everyone is well aware that accounting is one of the most important areas of economy, which has become so widespread in our lives today that it is impossible to imagine modern business and economy without this component. Accounting is a well thought out system that reflects the movement of various facts of economic life, no matter how different they are, and leads them into a common logical system. We can talk a lot about the features and possibilities of this science, but how often do we think about the ways this system arose, the ways of its development and becoming a separate science? During the study of this problem, an attempt was made to systematize various points of view regarding the origin and the development of accounting. After the result of the analysis, the authors identified regularities in the development of accounting and its methodical apparatus associated with the periodization of history on technological structures.
\end{abstract}

Keywords: History of accounting development, Sources of accounting, Accounting, Technoeconomic paradigm.

\footnotetext{
${ }^{1}$ Kazan Federal University, Institute of Management, Economics and Finance. E-mail: rinazmukhametzyanov@rambler.ru

${ }^{2}$ Kazan Federal University, Institute of Management, Economics and Finance.

${ }^{3}$ Financial University under the Government of the Russian Federation.
} 


\section{Introduction}

The history of any science is studied in order to ensure the continuity in its development so that it could be possible to know the laws of this development so as not to make the same discoveries twice. For the same reasons, we also study the history of accounting. The study of this science should be approached from the point of view of the way this phenomenon in history arose, what important stages in its development it passed, and to see what this phenomenon has become now from the point of view of its development (Paliy \& Sokolov, 1984: 250).

There is no unequivocal answer to the question, when the bookkeeping was born in the book "History of accounting development" by Ya. V. Sokolov, usually you can hear three answers (2004: 12):

- 6 thousand years ago, when people purposefully began to register the facts of economic life; - 500 years ago, when L. Pacholi's book was published ("The sum of arithmetic, geometry, the doctrine of proportions and relations") and the comprehension of accounting began;

- 100 years ago, when the first theoretical structures appeared in the field of accounting.

Accounting took a variety of forms, depending on the development level of production relations, productive forces, legislation, tradition, etc. (Galagan, 1927: 11). With the development of tools of labor, the system of economic relations, the information model reflecting them also became more sophisticated, the methods and the means of information processing were also improved. Proceeding from this, it can be assumed that at each stage of development, various prerequisites can be identified for the emergence and the development of accounting.

A sufficiently large number of studies from domestic and foreign scientists is devoted to the history of accounting, various philosophical, evolutionary and other approaches are known, which are very diverse in nature, cause the discussion on this issue.

\section{Materials and methods}

The authors analyzed various sources of information, in which the history of accounting origin and development is disclosed, as the materials for the study. The main base for the study was textbooks, monographs, candidate and doctoral dissertations, periodical literature on the topic of research, the scientific articles from journals, including the indexed ones in the database "Scopus", "Web on Science", etc. They used general scientific methods as a 
scientific tool for the study: analysis and synthesis, induction and deduction, analogy and comparison.

\section{Results and discussion}

As already noted, the accounting took a variety of forms in its development and the information model that reflects them was improved, and the methods and the means of information processing were improved over time. Proceeding from this, it can be assumed that it is possible to single out various prerequisites for the emergence and the development of accounting at each stage of development:

- the desire of a business manager to know how much and what property is in his estate, how much he owes to other estates and how much others owe him;

- the imperfection of tools, unsuccessful hunting, climate change from favorable to cold - in order to survive in such conditions, a person had to calculate the food supply;

- the development of social production, the division of labor and the exchange of its products;

- the distribution of writing and printing, the development of elementary arithmetic;

- the changes in the forms and the sizes of economic transactions, the development of capitalism, the development of accounting legislation.

In his book, V.T. Chaya notes that accounting appeared during the primitive communal system. The imperfection of the tools did not always allow us to earn enough livelihoods, hunting did not always succeed, and climate change from favorable to cold made to starve occasionally. In order to survive in such conditions, a man had to calculate the food reserve. Subsequently, the improvement of tools, the development of surpluses and the beginning of exchange contributed to the development of accounting (Kulikova, 2015: 98).

According to V.E. Kerimov's opinion account arose during the extreme antiquity, when a person needed to know how many and what exactly means he has for his existence and how much time he needs to spend to manufacture the necessary tools.

According to Ya.V. Sokolov, the first sources of accounting are hidden from us forever. However, we can state that accounting did not come immediately. Several conditions were necessary for the emergence of written records. First of all, economic activity should be sufficiently large; Secondly, it was necessary to write and develop elementary arithmetic. Their appearance created the basis for the emergence of written records, and the development of economic relations contributed to its ubiquitous dissemination (Sokolov, 2004: 23). 
According to V.E. Kerimov's opinion, the first traces of developed accounting systems are observed in ancient Egypt, where several thousand years ago people kept a record in the whistles of papyrus (on loose sheets). Babylonia became the birthplace of "card accounting", which were made of soft and moist clay in the form of plates. Greece was the homeland of the first counting device - the abacus (Vetoshkina et al, 2016: 5603).

At a certain stage of trade development, the category of people appeared engaged only in buying and selling of goods. The spread of mathematics and writing contributed to the emergence of another profession - an accountant.

At this time, the practice distinguished only the accounting by material data carriers. But regardless of a carrier type the accounting system developed gradually current registration system, which was imbued with the spirit of accounting naturalism. Its emergence was related to the need of people to record what was happening in their household. At first it was necessary to rewrite all the property that was in the household, and the reason for the emergence of inventory is related to this. But already with the passing of a short time the first inventors (accountants) noticed that some things have individual characteristics that are easy to describe and write down, and some are generic ones, which can be written down only with a single mass, grouped according to a single feature. The desire to group and generalize certain objects according to genealogical characteristics led to the emergence of conventional units of measurement ("conventional brick", "man-day"), which became a new step in the development of the accounting concept, departing from a purely naturalistic approach. Allocation of generic attributes in its turn led to the invention of accounts, and their use for the reflection of changes in economic means led to the emergence of simple accounting (Aletkin, 2014: 35).

Simple accounting allowed to control all the material and cash assets of an enterprise, but it should be noted that it was of a registration nature only, because it was not possible to determine the amount of profit, there were no results which allow to monitor the amounts reflected in the accounting automatically. The development of accounting realism was facilitated by the emergence of a double bookkeeping, the main feature of which is represented by the accounts of own funds. From this moment all economic processes were reflected with the help of a double entry. This, in its turn, made it possible to establish observation of such quantities as capital and profits that can neither be seen, nor touched, nor weighed, nor measured, since they were conditional and could be obtained in a purely accounting way. A serious impetus to the development of a double entry was the introduction of a single monetary meter, which made different things quantitatively commensurable (Kulikova, 2015: 252). 
V.T. Chaya divides the development process of accounting technology into three main stages within a general form: unigraphic, cameral and digraphic one.

The unigraphic record was characteristic of the primitive communal system of the ancient world (before the 15th century) and was the system of economic activity direct reflection, only property was considered as its object (for example, precious stones, fabrics, products).

Cameral accounting developed after the XIIth century. Its object was money: their expected and actual income and expenditure. It should be noted that this type of accounting existed in parallel with the unigraphic and digraphic accounting.

Digraphic (double) accounting is characterized by the representation of economic operations by double accounting, the object of which is not only property, but also the sources of its receipt. This kind of accounting on the territory of Europe was brought by Venetian merchants, who in its turn acquired the secret of doing business with the help of double counting from Arabs in the 9th century. This skill was transferred exclusively within the merchant clans for several centuries. Further, a systematic description of the sequential processing of information by double counting was suggested by the French monk Luca Pacioli in the "Treatise on Accounts and Records" (Paliy \& Sokolov, 1984).

Another category that authors distinguish a slightly different point of view, which is presented in Table 1.

Table 1 - Process of accounting development

\begin{tabular}{|l|l|}
\hline \multicolumn{1}{|c|}{ Period } & \multicolumn{1}{c|}{ Characteristics } \\
\hline Until 6000 years BC. & The emergence of accounting \\
\hline From 4000 BC. till 500 BC. & The naturalistic stage of development \\
\hline 500 BC -1300 & The cost of development \\
\hline $1300-1850$ & Digraphic stage of development \\
\hline $1850-1900$ & $\begin{array}{l}\text { Theoretical and practical stage of } \\
\text { development }\end{array}$ \\
\hline $1900-1950$ & Scientific stage of development \\
\hline 1950 and until our time & The current stage of development \\
\hline
\end{tabular}


Accounting as a science which has its own theory, the law of double entry of economic transactions, arose at the end of the Middle Ages. The homeland of double-entry bookkeeping is considered to be Italy, which is associated with L. Pacioli (Kulikova, 2015: 101).

In his treatise "On Accounts and Records" Luka Pacioli devoted three chapters to the balance. All these provisions formed the basis of the works by D. Cardano (1539), I. Manzoni (1549), B. Katruli (1573), L. Flory (1633) and other authors of Italy, J. Impin (1543) in Holland, I. Gottlieb (1531) in Switzerland and H. Oldcastle (1543) in England. A characteristic feature of this period was the absence of theoretical generalizations, which were worked out by practice, as well as the inability of authors to understand the essence of the phenomena occurring in connection with the processes in a particular state (Sokolov, 2004; Vetoshkina et al., 2016).

During these times, accounting was interpreted in legal and economic sense. For the first time the legal interpretation of accounting was given by Edmond Degrange (1797), who introduced the notion of an economic operation and claimed that at least two accounts are required for each operation: the one who receives, is debited, and an issuer is credited. The principles of the legal direction were most fully formulated by Francesco Villa (1864), who moved from personalization instead of an account identification with a person, he entered the accounts for individuals and interpreted all accounts as open ones for custodian agents, the accounting subject of which was represented by a contract (Sokolov, 2004: 253).

Together with the legal interpretation of accounting, economic interpretation of accounting appeared. Giuseppe Forney (1790) argued that the subject of accounting is represented not by physical and legal persons, subjects of rights and obligations, but by objects, things and values. All values are measured in money, and this turns them into a comparable and qualitatively homogeneous property.

Gradually the forms and sizes of economic operations changed and increased, and it was impossible to capture all these operations using the existing primitive means that the science of bookkeeping had at its disposal. The end of the XVIIIth and the first half of the XIXth century is characterized by an intensive development of the productive forces of society, as well as by the expansion of international trade. The accountant scientists of that time began to understand that it was not enough to confine themselves to the study and presentation of a single form alone, and that theoretical justifications of certain practical methods were necessary, the center of which had to be represented by the factor that is the most important in the activity of an enterprise, and from this point of view they started to proceed during the study of a particular private household activity (Kulikova \& Gafieva, 2014a: 41). 
The development of capitalism contributed to the further improvement of accounting: since the mid-19th century they began to reflect artificial values in accounting, such as cost, profit and depreciation.

The second half of the XIXth - the beginning of the XXth century is characterized by the stage of accounting development as a science. In most countries the accounting legislation is being developed during this period, an integral part of which was represented by a balance sheet and an income statement. During this period the legislation of many countries obliges entrepreneurs to publish their accounting reports in order to reduce the amount of risk from shareholders, investors and other external users (Mukhametzyanov \& Nugaev, 2016: 48).

The second half of XXth - the beginning of the XXIst century is characterized by an active implementation of international financial reporting standards, the development of accounting in conjunction with related sciences. Accounting is becoming one of the most important areas of the economy, which became widely spread in our lives nowadays (Kulikova \& Gafieva, 2014: 40).

Having considered the history of accounting development from various points of view, we came to the conclusion that it is expedient to single out the patterns associated with the periodization of history along techno-economic paradigms in the development of accounting and its methodical apparatus (Table 2).

Table 2. Regularity in the development of accounting and its methodical apparatus, associated with the periodization of history by techno-economic paradigms

\begin{tabular}{|c|c|c|c|c|}
\hline $\begin{array}{c}\text { First and second } \\
\text { techno-economic }\end{array}$ & $\begin{array}{c}\text { Third techno-economic } \\
\text { paradigm }\end{array}$ & $\begin{array}{c}\text { Fourth } \\
\text { techno- }\end{array}$ & $\begin{array}{c}\text { Fifth techno- } \\
\text { economic }\end{array}$ & $\begin{array}{c}\text { Sixth techno- } \\
\text { economic }\end{array}$ \\
paradigm (1730- & $(1881-1930)$ & $\begin{array}{c}\text { economic } \\
\text { paradigm }\end{array}$ & paradigm \\
& & paradigm & $(1981-2009)$ & (Since 2010 till \\
& & $(1931-1980)$ & & now) \\
\hline
\end{tabular}




\begin{tabular}{|c|c|c|c|c|}
\hline $\begin{array}{l}\text { - the } \\
\text { methodology of } \\
\text { accounting in the } \\
\text { direction of trade } \\
\text { and industrial } \\
\text { operation } \\
\text { processing is } \\
\text { being developed; } \\
\text { - the appearance } \\
\text { of the first } \\
\text { printed manuals } \\
\text { and textbooks on } \\
\text { accounting; } \\
\text { - for the first time } \\
\text { accounting is } \\
\text { mentioned as a } \\
\text { science }\end{array}$ & $\begin{array}{l}\text { - mathematical } \\
\text { description of } \\
\text { accounting procedure } \\
\text { based on the formal } \\
\text { theory of two series of } \\
\text { accounts; } \\
\text { - the division of } \\
\text { accounting into two } \\
\text { types: financial and } \\
\text { analytical and the } \\
\text { emergence of } \\
\text { managerial accounting } \\
\text { principles; } \\
\text { - the appearance of } \\
\text { professional } \\
\text { accountants; } \\
\text { - the emergence of } \\
\text { computing devices and } \\
\text { equipment; } \\
\text { - foundations of } \\
\text { accounting science } \\
\text { (accounting) are laid; } \\
\text { - the principles of } \\
\text { direct-costing were } \\
\text { formulated }\end{array}$ & $\begin{array}{l}\text { - the method } \\
\text { of cost } \\
\text { accounting } \\
\text { by the } \\
\text { responsibility } \\
\text { of centers } \\
\text { was } \\
\text { proposed; } \\
\text { - the solution } \\
\text { of strategic } \\
\text { management } \\
\text { tasks based } \\
\text { on the use of } \\
\text { computers } \\
\text { and a clear } \\
\text { division of } \\
\text { costs on } \\
\text { variables } \\
\text { proportional } \\
\text { to the volume } \\
\text { of production }\end{array}$ & $\begin{array}{l}\text { - the } \\
\text { development of } \\
\text { normative } \\
\text { documents on } \\
\text { accounting } \\
\text { - the } \\
\text { development } \\
\text { and } \\
\text { implementation } \\
\text { of International } \\
\text { Accounting and } \\
\text { Auditing } \\
\text { Standards } \\
\text { - change in the } \\
\text { nature of } \\
\text { accounts - the } \\
\text { transition from } \\
\text { the accounting } \\
\text { of enterprises to } \\
\text { the accounting } \\
\text { of the entire } \\
\text { national } \\
\text { economy }\end{array}$ & $\begin{array}{l}\text { - the } \\
\text { development } \\
\text { and the } \\
\text { implementation } \\
\text { of International } \\
\text { Accounting and } \\
\text { Auditing } \\
\text { Standards } \\
\text { - the use of } \\
\text { modern } \\
\text { computer } \\
\text { facilities }\end{array}$ \\
\hline
\end{tabular}

The emergence of accounting as a separate science is associated with the growth of the social product, the development of industry and the transition from manufactory production to capitalist production. The concentration of capital led to the growth of labor productivity on the basis of technological achievements, an explosive growth of production, management and financial activity led to the further development and emergence of a number of applied sciences such as management accounting, economic analysis, audit, statistics, management, marketing, personnel management, etc. (Ushakova \& Mukhametzyanov, 2015: 101. 


\section{Conclusion}

The results of the conducted study show that the appearance of accounting is hidden from us forever. The history of this science is studied in order to ensure the continuity in its development, so that it is possible to know the laws of this development and not to make the same discoveries twice. Accounting took a variety of forms in its development and over time, the information model that reflects them was improved, and the methods and the means of information processing were improved. In this regard, we identified various prerequisites for the emergence and the development of accounting at each stage of its development. Considering different points of view on the development of this science, we revealed the regularity in the development of accounting and its methodical apparatus, connected with the periodization of history along techno-economic paradigms.

\section{Acknowledgements}

The work is performed according to the Russian Government Program of Competitive Growth of Kazan Federal University.

\section{References}

Aletkin, P. A. (2014). International Financial Reporting Standards Implementation into the Russian Accounting System. Mediterranean Journal of Social Sciences, 5(24), 33-37.

Galagan, A. M. (1927). Accounting in its historical development. M.: L.

Kulikova, L. I. (2015). The historical aspect of bookkeeping science origin and development. Bulletin of Adygei State University. Series 5: The Economy, 3(165), 97-105.

Kulikova, L. I. \& Gafieva, G. M. (2014a). Falsification of financial statements: Historical and evolutionary aspect. Mediterranean Journal of Social Sciences 5(24), 41-43.

Kulikova, L. I. \& Gafieva, G. M. (2014 b). Development of financial reporting principles. Mediterranean Journal of Social Sciences, 5(24), 38-40.

Mukhametzyanov, R. Z. \& Nugaev, F. S. (2016). Financial statements as an information base for the analysis and management decisions. Journal of Economics and Economic Education Research, Special Issue, 2, 47-53.

Paliy, V. F. \& Sokolov, Ya. V. (1984). Theory of Accounting: Textbook. Moscow: Finance and Statistics.

Sokolov, Ya. V. (2004). History of Accounting: A Textbook. Moscow: Finance and Statistics. 
Ushakova, T. V. \& Mukhametzyanov, R. Z. (2015). Economic analysis within the framework of organization life cycle concepts. Kazan economic herald, 3(17), 99-103.

Vetoshkina, E. Y.; Ivanovskaya, A. V. \& Akhmedzyanova, F. N. (2016). Uncompensated property receipt accounting operations. International Business Management, 10(23), 56035606. 